\title{
The alteration of neuronal activities of the cuneiform nucleus in non-hypovolemic and hypovolemic hypotensive conditions
}

\author{
Alterações da atividade neuronal no núcleo cuneiforme em condições hipovolêmicas e \\ não hipovolêmicas
}

Reza MOHEBBATI', Hassan ABBASSIAN²,3, Mohammad Naser SHAFEI', Ali GORJI2,5,6, Sajad Sahab NEGAH L $^{2,5}$

\begin{abstract}
Background: The cuneiform nucleus is located in the center of the circuit that mediates autonomic responses to stress. Hemorrhagic hypotension leads to chemoreceptor anoxia, which consequently results in the reduction of baroreceptor discharge and stimulation of the chemoreceptor. Objective: Using the single-unit recording technique, the neuronal activities of the cuneiform nucleus were investigated in hypotensive states induced by hemorrhage and administration of an anti-hypertensive drug (hydralazine). Methods: Thirty male rats were divided into the control, hemorrhage, and hydralazine groups. The femoral artery was cannulated for the recording of cardiovascular responses, including systolic blood pressure, mean arterial pressure, and heart rate. Hydralazine was administered via tail vein. The single-unit recording was performed from the cuneiform nucleus. Results: The maximal systolic blood pressure and the mean arterial pressure significantly decreased and heart rate significantly increased after the application of hydralazine as well as the following hemorrhage compared to the control group. Hypotension significantly increased the firing rate of the cuneiform nucleus in both the hemorrhage and hydralazine groups compared to the control group. Conclusions: The present data indicate that the cuneiform nucleus activities following hypotension may play a crucial role in blood vessels and vasomotor tone.
\end{abstract}

Keywords: Hemorrhage; Blood Pressure; Cardiovascular System; Hydralazine; Electrophysiology.

\section{RESUMO}

Antecedentes: O núcleo cuneiforme está localizado no centro do circuito que media as respostas autonômicas ao estresse. A hipotensão hemorrágica leva àanóxia dos quimiorreceptores, que, consequentemente, resulta na redução da descarga dos barorreceptores eestimulação do quimiorreceptor. Objetivo: Utilizando a técnica de registro em unidade única, as atividades neuronais do núcleo cuneiforme foram investigadas em estados de hipotensão induzida por hemorragia e administração de um anti-hipertensivo (hidralazina). Métodos: Trinta ratos machos foram divididos nos grupos controle, hemorragia e hidralazina. A artéria femoral foi canulada, para o registro de respostas cardiovasculares, incluindo pressão arterial sistólica, pressão arterial média e frequência cardíaca. A hidralazina foi administrada na veia da cauda. 0 registro de unidade única foi realizado a partir do núcleo cuneiforme. Resultados: A pressão arterial sistólica máxima e a pressão arterial média diminuíram significativamente, e a frequência cardíaca aumentou significativamente após a aplicação de hidralazina, bem como a hemorragia seguinte, em comparação com o grupo controle. A hipotensão aumentou significativamente a taxa de disparo da população do núcleo cuneiforme em ambos os grupos de hemorragia e hidralazina, em comparação com o grupo de controle. Conclusões: Os presentes dados indicam que as atividades do núcleo cuneiforme após hipotensão podem desempenhar um papel crucial nos vasos sanguíneos e no tônus vasomotor.

Palavras-chave: Hemorragia; Pressão Sanguínea; Sistema Cardiovascular; Hidralazina; Eletrofisiologia.

\footnotetext{
'Applied Biomedical Research Center, Mashhad University of Medical Sciences, Mashhad, Iran.

${ }^{2}$ Neuroscience Research Center, Mashhad University of Medical Sciences, Mashhad, Iran.

${ }^{3}$ Sleep Clinic, Imam Reza Hospital, Mashhad University of Medical Sciences, Mashhad, Iran.

${ }^{4}$ Department of Physiology, Faculty of Medicine, Mashhad University of Medical Sciences, Mashhad, Iran.

${ }^{5}$ Shefa Neuroscience Research Center, Khatam Alanbia Hospital, Tehran, Iran

${ }^{6}$ Epilepsy Research Center, Department of Neurosurgery and Department of Neurology, Westfälische Wilhelms-Universität Münster, Münster, Germany. RM (D) https://orcid.org/0000-0002-1645-7094; HA (D) https://orcid.org/0000-0001-9878-7670; MNS (D) https://orcid.org/0000-0001-5148-9895; AG (ID) https://orcid.org/0000-0002-4557-3270; SSN (D) https://orcid.org/0000-0002-2242-9794

Correspondence: Sajad Sahab Negah; Email:Sahabnegahs@mums.ac.ir.

Conflict of interest: There is no conflict of interest to declare.

Authors' contributions: RM: conceptualization, data curation, investigation, methodology, project management, software and writing of the first draft; HA: investigation, methodology, software and validation; MNS: formal analysis, methodology, visualization and writing of the first draft; AG: funding acquisition, project management, supervision, validation, writing, reviewing and editing; SSN: conceptualization, data curation, investigation, supervision and writing, reviewing and editing.

Received on December 03, 2020; Received in its final form on February 02, 2021; Accepted March 05, 2021.
} 


\section{INTRODUCTION}

The central nervous system plays a central role in regulating hypotension during hypovolemia and non-hypovolemic hypotension. Baroreceptors and chemoreceptors are activated by low blood pressure ${ }^{1}$. This afferent information is transmitted by carotid receptors (chemo- and baroreceptors) to the nucleus of the solitary tract (NTS) ${ }^{2}$. Thereafter, signals from the nucleus tractus solitarius (NTS) project to several brain areas that are involved in cardiovascular regulation, such as the caudal ventrolateral medulla (CVLM), paraventricular nucleus (PVN), and the rostral ventrolateral medulla (RVLM $)^{2}$, to restore blood pressure to normal range. Despite intensive investigations, the exact modulatory mechanism of different brain regions during hypotension needs to be elucidated.

The cuneiform nucleus $(\mathrm{CnF})$, a reticular nucleus of the midbrain, is a mesencephalic area implicated in several functions, including regulation of the cardiovascular system, pain modulation, sleep, and movement ${ }^{3}$. The $\mathrm{CnF}$ is reciprocally connected to different brain areas involved in the regulation of the cardiovascular system, such as the Kolliker-Fuse nucleus (KF), the periaqueductal gray matter (PAG), the NTS, the locus coeruleus, the raphe nucleus, the lateral hypothalamus, PVN, and the RVLM ${ }^{4}$. The $\mathrm{CnF}$ is located in the center of a circuit that mediates autonomic responses related to stress. This circuit has two parts: a sympathetic part that increases the blood pressure and a parasympathetic part that decreases the heart rate $^{5}$. However, it is reported that the most effective area of the $\mathrm{CnF}$ is the sympathoexcitatory area, through which electrical or chemical stimulation increases the arterial blood pressure ${ }^{6}$.

Hypotension disrupts blood supply to the tissues, which may lead to tissue hypoxia ${ }^{7}$. Hypovolemic (hemorrhage) and non-hypovolemic (heart failure, sepsis, and drug-induced vasodilation) factors are common causes of severe hypoten$\operatorname{sion}^{8}$. Several brain areas such as the preoptic area, PVN, and RVLM are involved in the regulation of the cardiovascular system during hypotension. In addition, the $\mathrm{CnF}$ might also be involved in this process. It has been reported that hemorrhage increases expression of $\mathrm{C}$-fos in the $\mathrm{CnF}$, as well as the functional interconnection between the $\mathrm{CnF}$ and PVN and NTS areas that are involved in hypotension'. Furthermore, the glutamatergic, cholinergic, serotonergic, and opioidergic pathways that are involved in hypotension are found in the $\mathrm{CnF}^{4,10,11,12,1,1,14}$. However, the exact mechanism of the $\mathrm{CnF}$ action during hypotension and whether this nucleus is involved in hypovolemic (induced by hemorrhage) or nonhypovolemic (induced by hydralazine, a vasodilator drug) hypotension is still not elucidated. Therefore, the present study aimed to investigate blood pressure response and neuronal activities of the $\mathrm{CnF}$ following hypovolemic and nonhypovolemic hypotension in rats.

\section{METHODS}

\section{Animals and surgery}

Thirty Wistar rats $(220-250 \mathrm{~g})$ were provided from the animal house of the Faculty of Medicine of Mashhad. Animals were kept in a 12-h light-dark cycle, constant temperature $\left(22 \pm 2^{\circ} \mathrm{C}\right)$, and were allowed free access to standard laboratory diet and water. Experiments were approved by the Ethics Committee of Mashhad University of Medical Sciences. Animals were anesthetized with urethane $(1.5 \mathrm{~g} / \mathrm{kg}$, i.p.; Sigma, USA) and supplementary doses $(0.7 \mathrm{~g} / \mathrm{kg})$ were given if necessary ${ }^{15}$. The body temperature of the animal was maintained at $37^{\circ} \mathrm{C}$ with a thermostatically controlled heating lamp. A polyethylene catheter (PE-50) was inserted into the femoral artery for blood pressure recording by the Power Lab instrument ${ }^{15}$. Animals were secured on stereotaxic apparatus and a hole was drilled above the $\mathrm{CnF}$ region according to the coordinates of the Paxinos atlas (Anterior-posterior; -7.6 to -8.5 , Lateral; 1.7 to 2.2 and Height; -5.5 to $-6.2^{16}$.

\section{Recordings of cardiovascular and neuronal activities}

Blood pressure (BP) and heart rate (HR) were continuously recorded by an MLT844 pressure transducer coupled to a preamplifier (FE221 Bridge amplifier, AD instruments, AU) connected to a Power Lab 4/35 data acquisition system (model PL3504 AD instruments, AU). The animals were mounted on the stereotaxic apparatus and a microdrive was used for positioning and lowering the electrode into the $\mathrm{CnF}$. The electrode slowly lowered $(2 \mu \mathrm{m} / \mathrm{sec})$ under continuous recording of neuronal signals until an active neuron was isolated. Administration of hydralazine or the induction of hemorrhage was done for a 15-min session and the spike firing rate was recorded for a subsequent period of $30 \mathrm{~min}$. The recordings were filtered between 300 and $3 \mathrm{k} \mathrm{Hz}$ with a resolution of $24 \mathrm{bits} / \mathrm{SPS}$ and analyzed in offline mode. Spike sorting and clustering was performed using the e-lab software. Spike sorting and peri-stimulus time histograms (the number of spikes per discrete time; PSTH) were built using compatible E sorter software. After determining the appropriate gain in raw data in the offline sorter, the number of clusters between 4 to 8 in the whole session (1800 seconds) was measured.

\section{Experimental design}

The male Wistar rats $(\mathrm{n}=30)$ were randomly divided into three groups; (i) control group that received saline (i.v); (ii) hydralazine group that received hydralazine $(200 \mu \mathrm{g} / \mathrm{kg}$, i.v; Sobhan Daru, Iran), and (iii) hemorrhage group, which bleeding was performed from the tail vein. The application of saline or hydralazine, as well as the bleeding from the tail vein, was performed after stable recordings of both blood pressure and spike activity of the $\mathrm{CnF}$. Hydralazine and saline were injected into the systemic blood flow via tail vein. Hypotension was induced by bleeding from the tail vein to reach a 40-50 mmHg decrease in mean arterial pressure (MAP). Evaluation of cardiovascular parameters and single unite recordings were performed for 1,800 seconds (Figure 1). 
At the end of each experiment, the animal was sacrificed by a high dose of urethane. The brain was then removed and stored in $10 \%$ formalin for $24 \mathrm{~h}$. The electrode sites were determined according to a rat brain atlas under a light microscope ${ }^{16}$.

\section{Data analysis}

MAP and HR values were expressed as mean \pm SEM. The cardiovascular response and the neuronal firing patterns for each injection were aligned and compared with the control. The maximum changes of systolic blood pressure (SBP), MAP, and HR and firing rate of neurons were compared with those of the pre-injection and the control values by one way ANOVA followed by Tukey post-hoc test. $\mathrm{P}<0.05$ was used to indicate statistical significance. Correlation between variables in each group was assessed by the Pearson test in Statistical Package for the Social Sciences (SPSS) v11.5.

\section{RESULTS}

\section{Cardiovascular parameters}

A significant difference was observed in HR $(p<0.001)$, SBP $(p<0.001)$, and MAP $(p<0.001)$ between the control, hydralazine, and hemorrhage groups. The results showed that in the hydralazine group, the maximal changes of SBP $(-35.5 \pm 1.8$ vs $-1.5 \pm 2.2 ; \mathrm{p}<0.001)$ and MAP $(-28.2 \pm 1.7$ vs $-1.1 \pm 1.9 ; \mathrm{p}<0.001)$ were significantly lower and the alteration of HR (58.3 \pm 10.5 vs 3.2 \pm 5.6 ; $p<0.01)$ was significantly higher compared with the control group. Furthermore, the changes of SBP $(-40.6 \pm 3.7$ vs $-1.5 \pm 2.2$ in the control group; $p<0.001)$ and MAP $(-30.5 \pm 3.3$ vs $-1.1 \pm 1.9 ; \mathrm{p}<0.001)$ in the hemorrhage group were significantly lower, and the alterations of HR were significantly higher (65.4 17.4 vs $3.2 \pm 5.6$; $\mathrm{p}<0.01)$ compared with the control group (Figures 2 and 3).
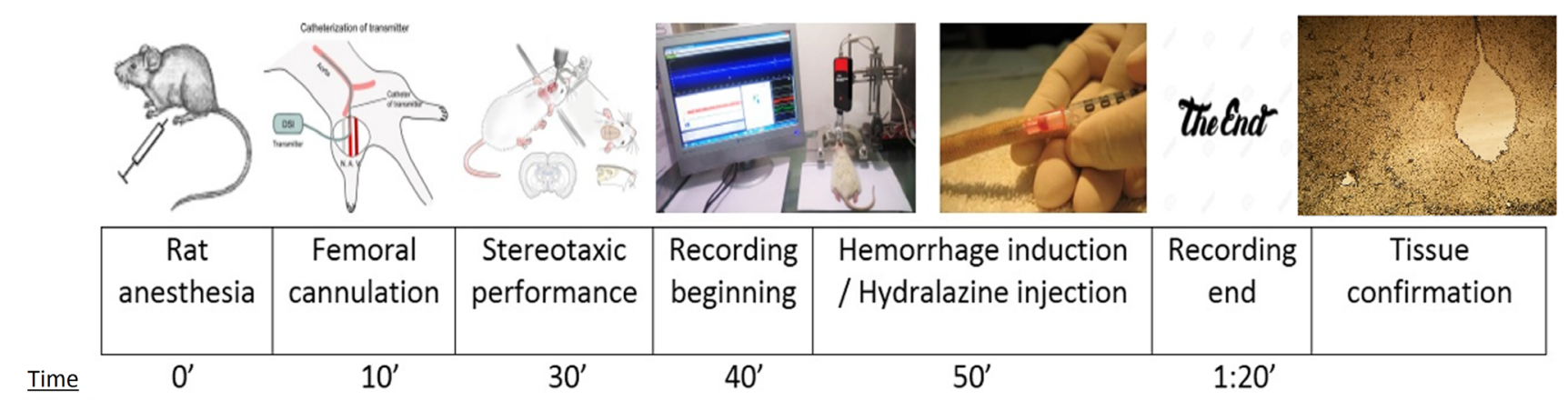

Figure 1. Diagram of the experimental design.
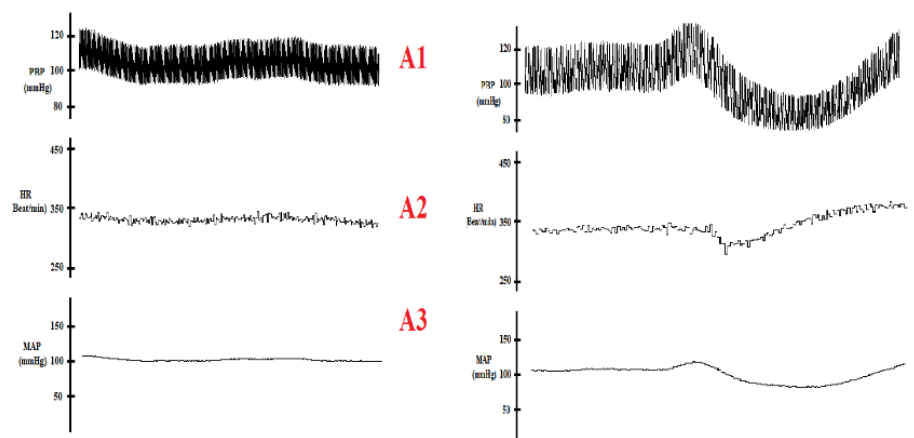

B1

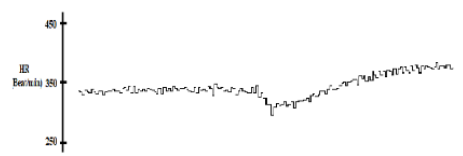

B2
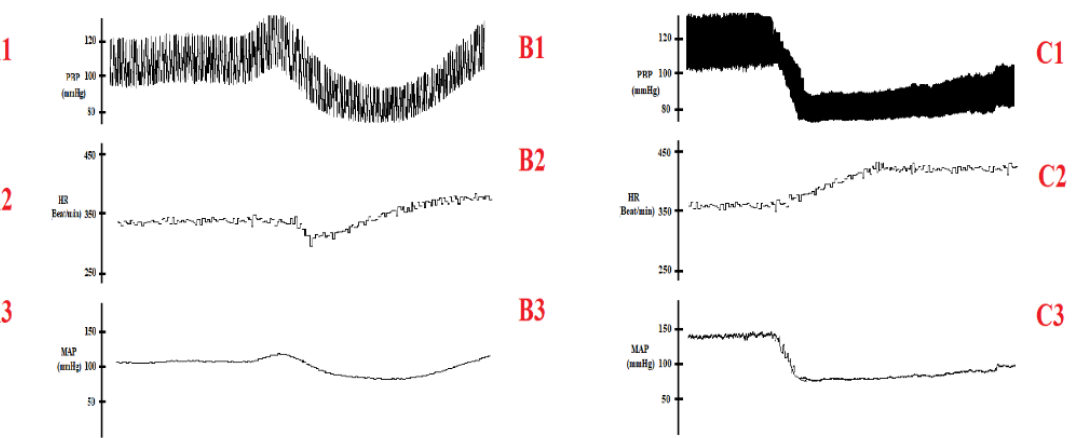

B3
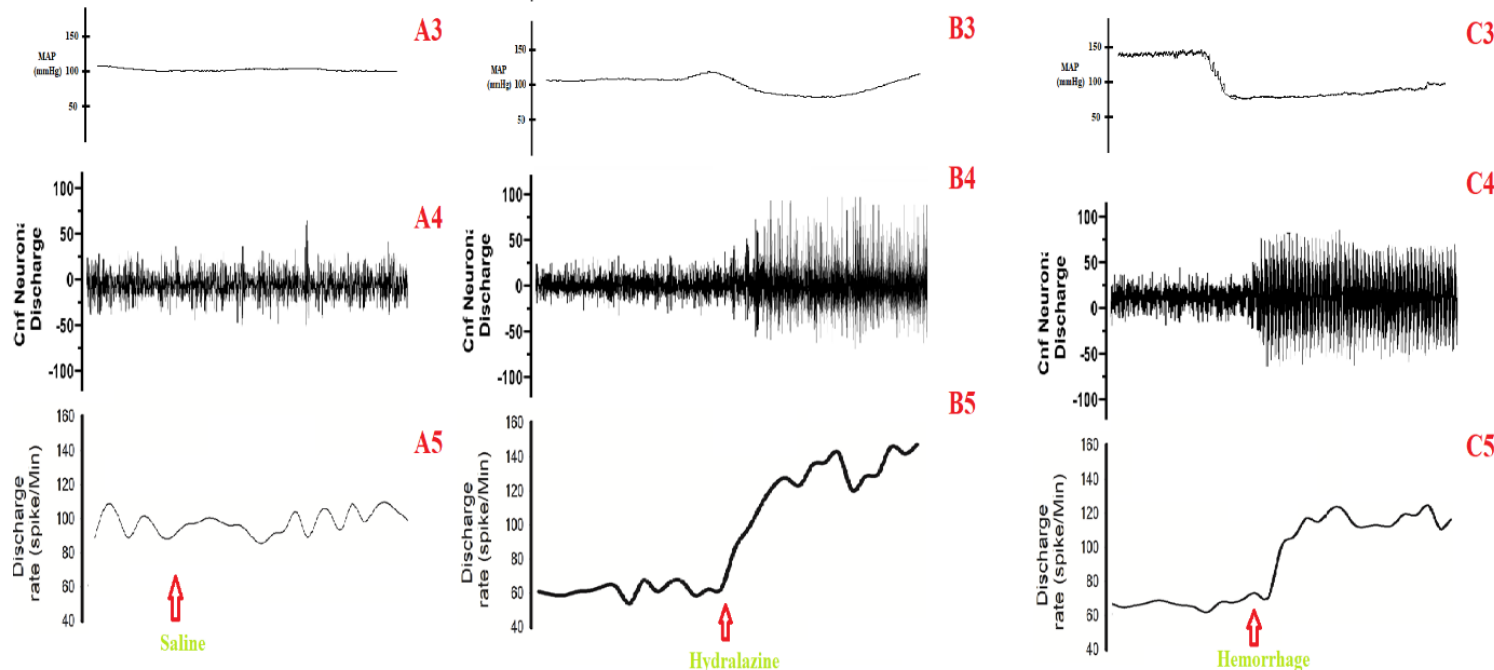

B4

C4
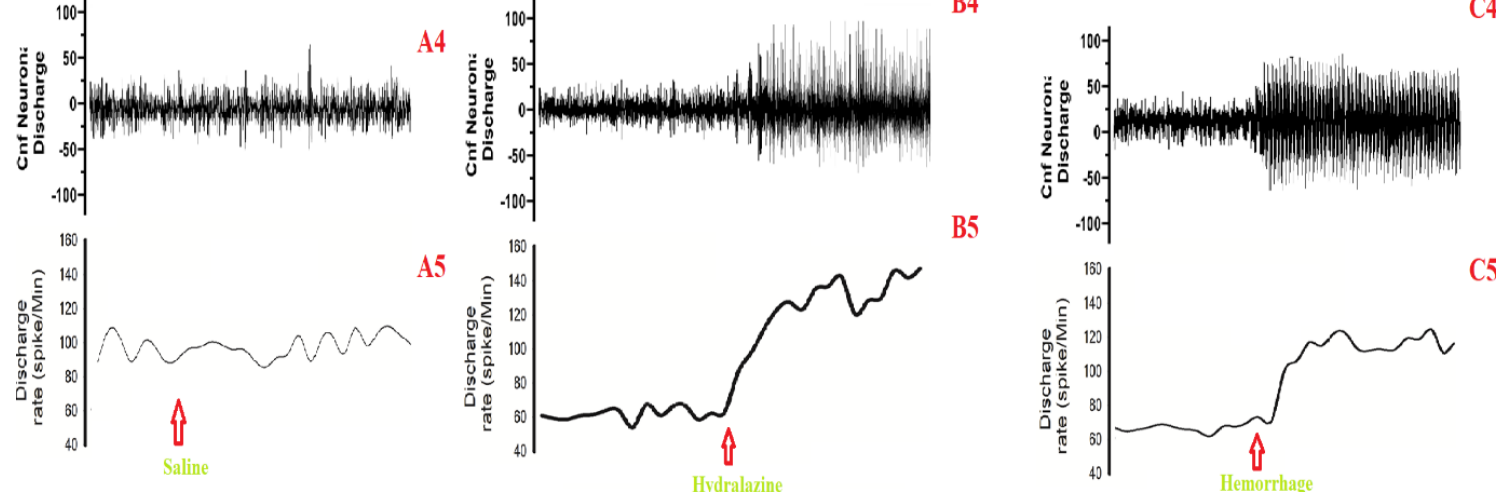

Figure 2. Representative recording of cardiovascular parameters $(1,2,3)$ and neural discharge $(4,5)$ after injection of saline (A), injection of hydralazine (B), and hemorrhage (C). 

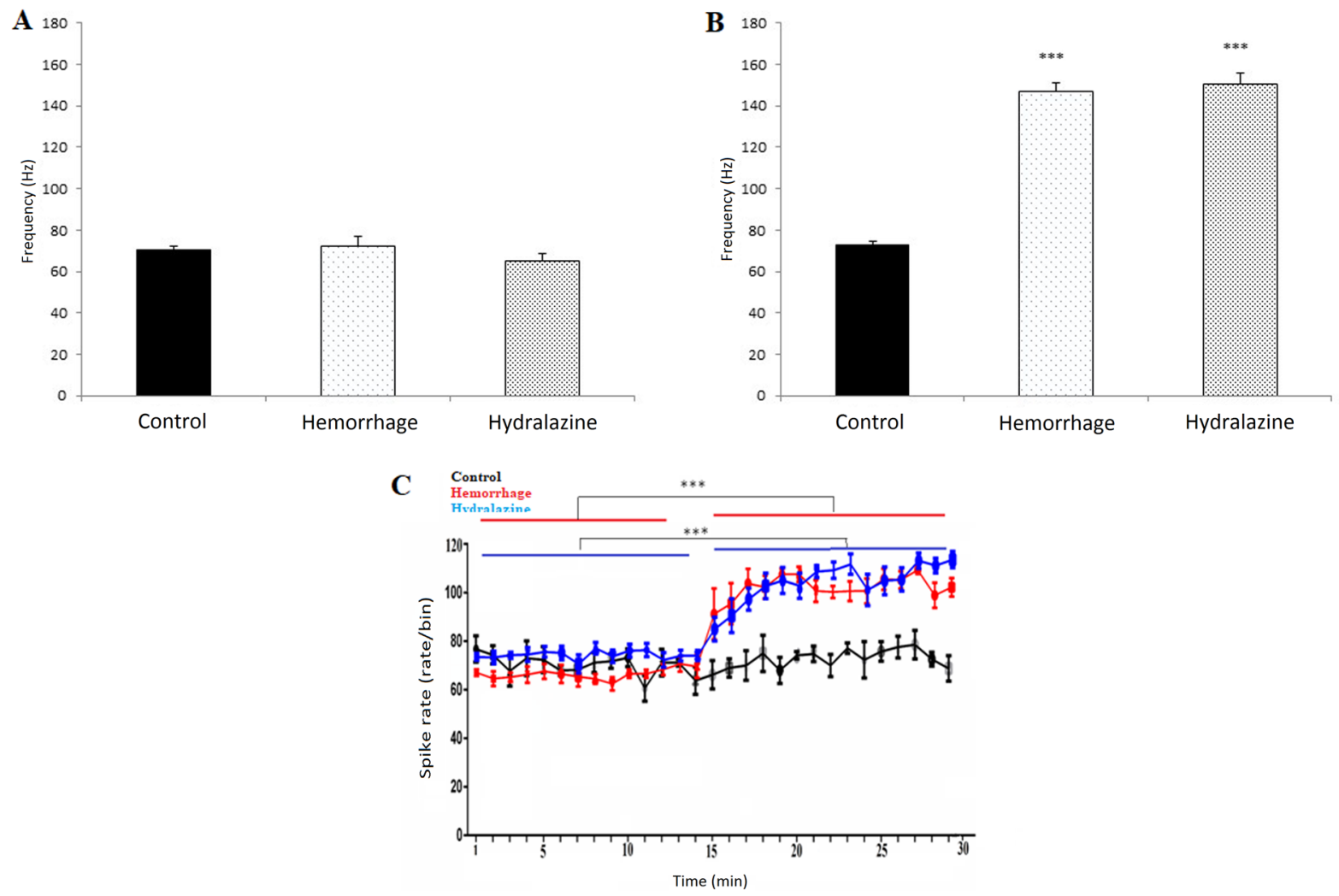

D

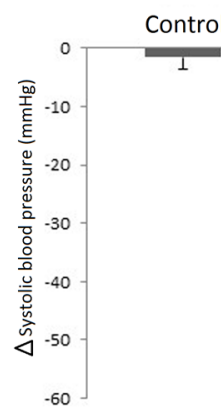

E

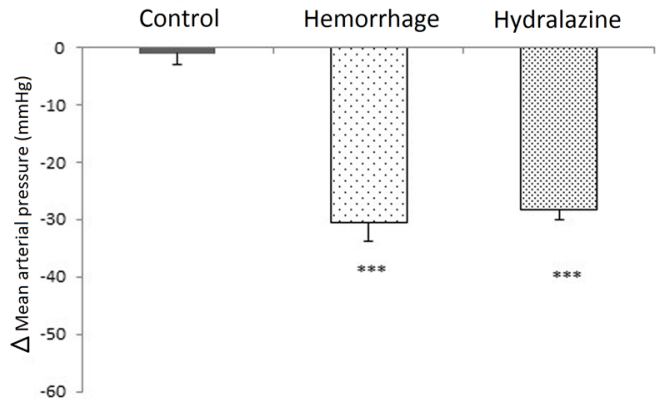

$\mathbf{F}$

Hydralazine
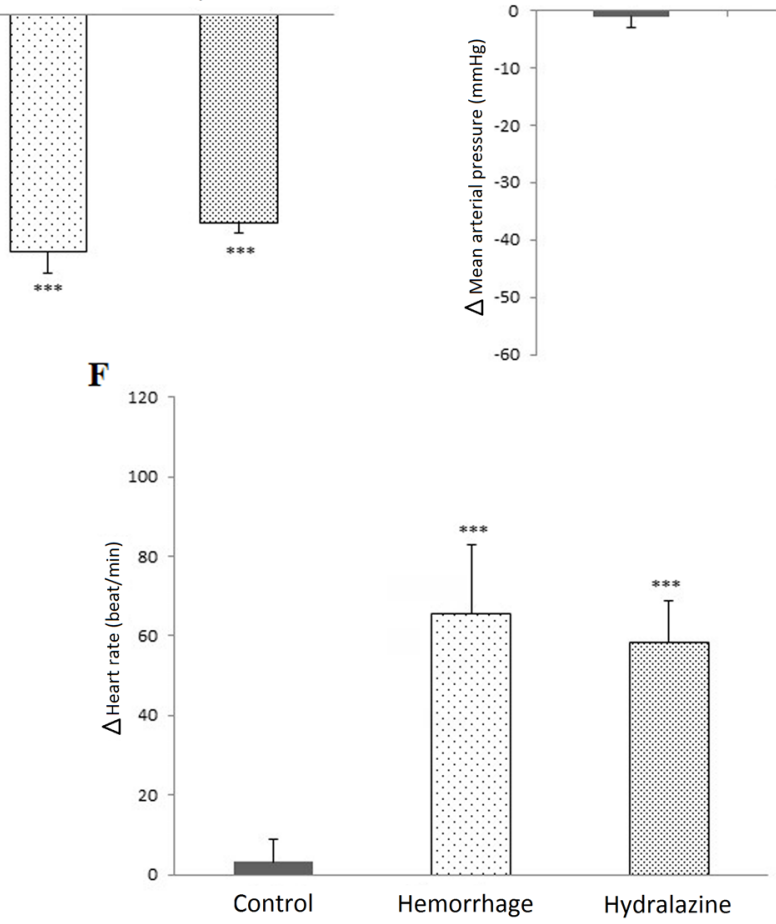

Figure 3. The spike rate and cardiovascular parameters analysis was performed from the Cuneiform nucleus in different experimental groups. Data represent BIN size spike rate (count/time) in the control, hemorrhage, and hydralazine groups (A, B, C). A paired t-test was used for statistical analysis. ${ }^{* *} \mathrm{p}<0.01$ indicates differences between before (A) and after (B) induction in each group. A comparison of the mean spike rate per BIN between different groups was measured before and after hypotension induction (C) ( $n=5 /$ each group). The data is expressed as mean \pm SEM. One-way ANOVA was used for statistical analysis. $* * * p<0.001$ indicates significant differences with the control group. Effects of hydralazine and hemorrhage on maximal change $(\Delta)$ of SBP (D), MAP (E), and HR (F) in anesthetized rats ( $n=5$ /each group) are shown. The data were compared with the control group and presented as mean \pm SEM. One-way ANOVA was used for statistical analysis. ${ }^{*} * \star p<0.001$ indicates significant differences with the control group. 


\section{Single unit recording}

No significant differences in the $\mathrm{CnF}$ firing rate were observed between different groups before the induction of hypotension. After the induction of hypotension by hemorrhage or hydralazine, a significant increase in the firing rate was observed $(\mathrm{p}<0.001)$. Furthermore, a significant enhancement of PSTH was recorded after the induction of hypotension $(\mathrm{p}<0.01)$. The analysis of the amplitude changes and the repetition rate of the population firing showed a significant enhancement of more than $20 \%$ in the hemorrhage and hydralazine groups after the induction of hypotension (Figures 2, 3, and 4). However, there was no significant correlation between the changes in the cardiovascular parameters and neural firing pattern.

The linear regression analysis showed that the firing rate was significantly correlated with increased time in the hemorrhagic and hydralazine groups but was stable in the control. ((Control: Slope $=0.1130, \mathrm{~F}: 1.273, \mathrm{p}=0.2612$ deviation from zero); (Hemorrhage: Slope $=4.429, \mathrm{~F}: 258.9, \mathrm{p}<0.0001$ ); (Hydralazine: Slope=4.171, F: 292.1, p<0.0001)) (Figure 5).

\section{Correlation}

The Pearson test showed a non-significant correlation between cardiovascular parameters and neural frequency (Table 1).

Figure 6 shows the electrode sites determined according to a rat brain atlas.
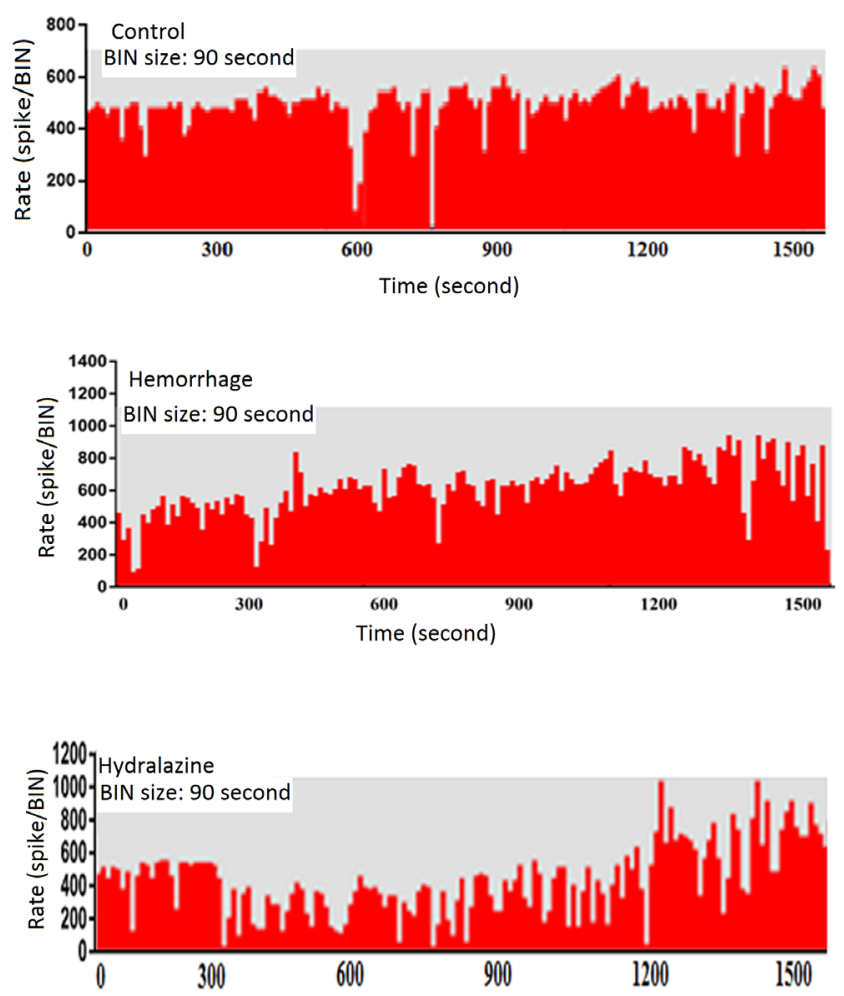

Figure 4. Pre-stimulus time histogram (BIN size $=90$ seconds recorded by "eLAB C apparatus Science Beam. Co.") in the control, hemorrhage, and hydralazine groups showed a significant increase in firing rates after induction of hemorrhage or injection of hydralazine.
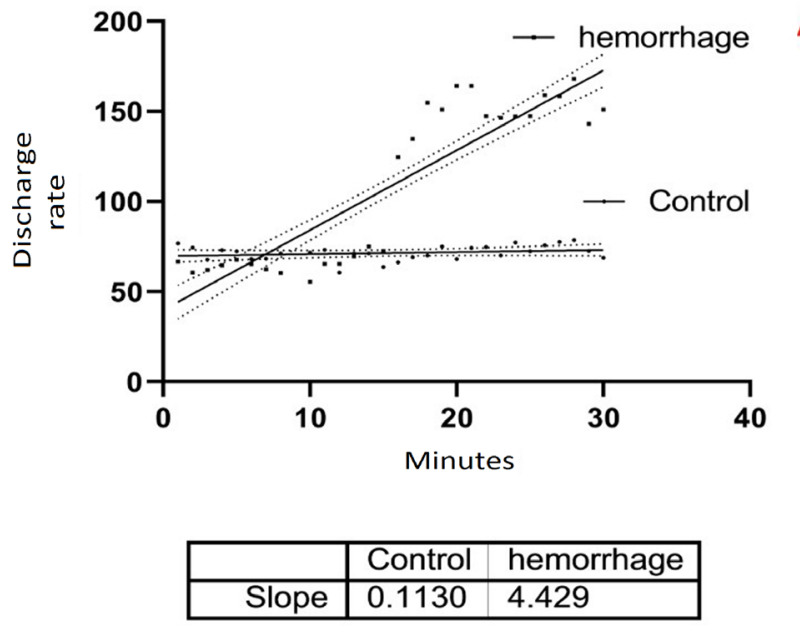

B

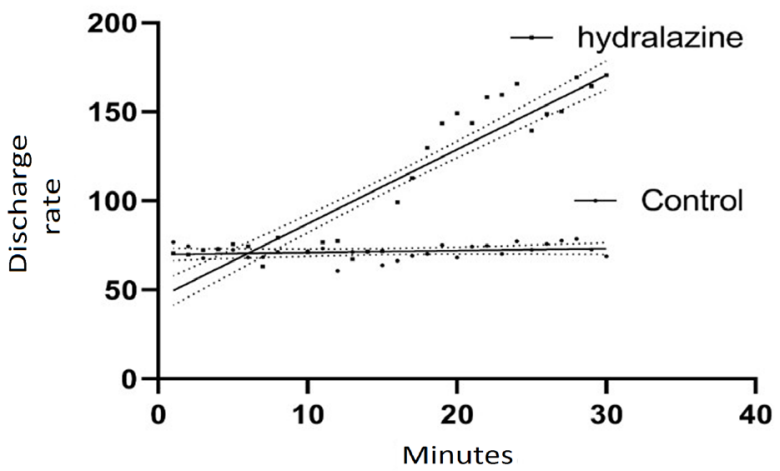

\begin{tabular}{|l|l|l|}
\hline & Control & hydralazine \\
\hline Slope & 0.1130 & 4.171 \\
\hline
\end{tabular}

Figure 5. The linear regression of control vs hemorrhagic and hydralazine groups (Control vs hemorrhage 0.1130/4.429 (A) and control vs hydralazine 0.1130/4.171) (B).

Table 1. Correlation between cardiovascular parameters and neural frequency.

\begin{tabular}{|c|c|c|c|c|c|}
\hline & & HR & SBP & MAP & Frequency \\
\hline \multirow[t]{2}{*}{$\mathrm{HR}$} & $\begin{array}{l}\text { Pearson } \\
\text { correlation }\end{array}$ & 1 & -0.970 & -0.978 & 0.763 \\
\hline & $p$-value & & 0.156 & 0.134 & 0.448 \\
\hline \multirow[t]{2}{*}{ SBP } & $\begin{array}{l}\text { Pearson } \\
\text { correlation }\end{array}$ & -0.970 & 1 & 0.999 & -0.897 \\
\hline & $p$-value & 0.156 & & $0.022 *$ & 0.291 \\
\hline \multirow[t]{2}{*}{ MAP } & $\begin{array}{l}\text { Pearson } \\
\text { correlation }\end{array}$ & -0.978 & $0.999^{*}$ & 1 & -0.881 \\
\hline & p-value & 0.134 & 0.022 & & 0.314 \\
\hline \multirow[t]{2}{*}{ Frequency } & $\begin{array}{l}\text { Pearson } \\
\text { correlation }\end{array}$ & 0.763 & -0.897 & -0.881 & 1 \\
\hline & $p$-value & 0.448 & 0.291 & 0.314 & \\
\hline
\end{tabular}

*Correlation is significant at the 0.05 level (2-tailed $p$ value). HR: heart rate, SBP: systolic blood pressure, MAP: mean arterial pressure. 


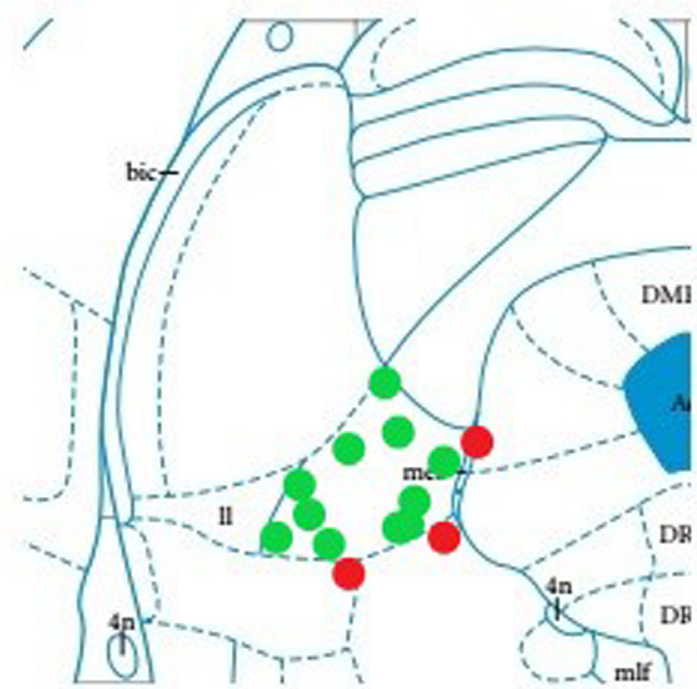

$-7.68 \mathrm{~nm}$

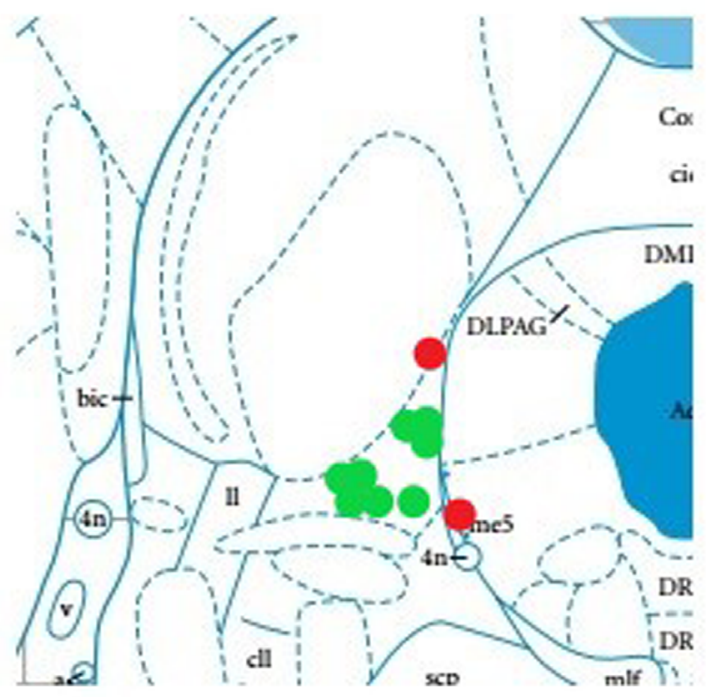

$-8.16 \mathrm{~nm}$

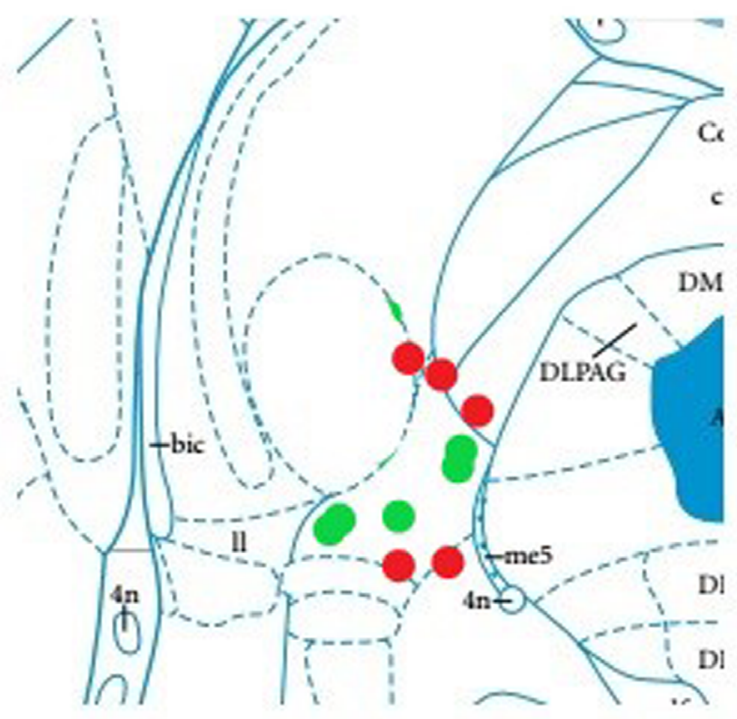

$-7.92 \mathrm{~nm}$

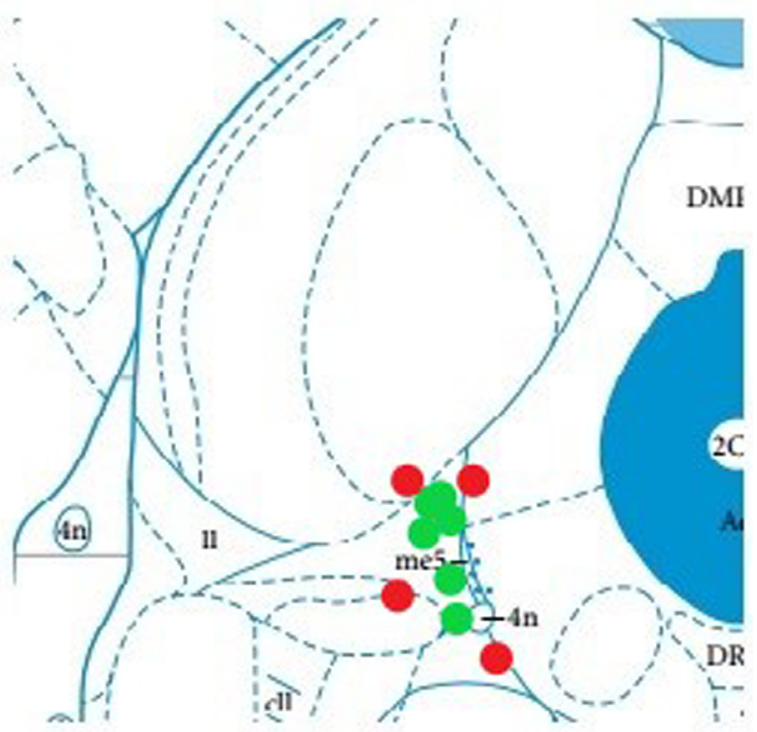

$-8.4 \mathrm{~nm}$

Figure 6. Schematic section of the rat brain adapted from Paxinos and Watson atlas. The electrode sites in the $\mathrm{CnF}$ are shown: green points are adequate and red points are out of range.

\section{DISCUSSION}

In this study, we used the single-unit electrophysiological recording to evaluate responses of the $\mathrm{CnF}$ neurons in hypotension induced by hypovolemic hemorrhage and non-hypovolemic (hydralazine) conditions. Our results showed that the firing rate of the $\mathrm{CnF}$ neurons increased in both conditions, which confirms the role of this nucleus in cardiovascular regulation. In previous studies, the modulatory effect of the $\mathrm{CnF}$ on the cardiovascular system in normotensive rats has evaluated ${ }^{13,14}$. Shafei et al. have shown that microinjection of glutamate into the $\mathrm{CnF}$ increased $\mathrm{BP}$ and that the cholinergic system has an inhibitory effect on the cardiovascular system ${ }^{11}$. In addition, it has been reported that $\mathrm{CnF}$ do not project directly to the spinal cord or areas involved in cardiovascular regulation specially RVLM and that these projections are mediated via areas such as KF and dIPAG. In line with these results, Nasimi et.al in an electrophysiological study in normotensive rats indicated that chemical stimulation of the CnF produces several patterns of neural activity and these responses correlate with various blood pressure responses ${ }^{4}$. Activation of the $\mathrm{CnF}$ neurons during hypotension in this study correlated with neural activity and blood pressure but not significantly. The reasons for this are not 
clear but we speculate that $\mathrm{CnF}$ has neurons that respond to both isovolemic and hypovolemic hypotension. Neural activation of $\mathrm{CnF}$ during hemorrhage is in line with our previous studies that indicate the involvement of $\mathrm{CnF}$ in the regulation of cardiovascular parameters during hypovolemic hypotension ${ }^{17}$. However, the lack of correlation may be due to the multi-synaptic neural pathway of the $\mathrm{CnF}$ nucleus. For example, it has been shown that the cardiovascular effect of $\mathrm{CnF}$ is mostly mediated by the KF nucleus. Therefore, $\mathrm{CnF}$ may activate the neuron population in $\mathrm{KF}$ and these neurons can be responsible for the regulation of blood pressure. In addition, $\mathrm{CnF}$ is a heterogeneous nucleus with numerous neurons with different effects. Therefore, we speculate that during hypotension all of these neurons activate and cause several responses that disrupt those correlations. However, further studies are needed to investigate these effects.

In a hypotension condition, baroreflex, as a compensatory reflex, is activated by baroreceptors located in the carotid body and arch of the aorta. Because the $\mathrm{CnF}$ is involved in the sympathetic part of the baroreflex (NTS, CVLM, RVLM), we hypothesize that the autonomic effect of the $\mathrm{CnF}$ is mostly mediated by the sympathetic system ${ }^{18}$. In non-hypovolemic hypotension induced by hydralazine, the cardiovascular effect of the $\mathrm{CnF}$ is mediate by the NTS-CVLM-RVLM pathway. It has been reported that the projection of the $\mathrm{CnF}$ to RVLM is indirect and probably mediated by PAG, KF, and raphe nuclei. We believe that the CnF-dlPAG-RVLM pathway is involved in the regulation of the cardiovascular system in conditions such as stress and exercise $\mathrm{e}^{19,20,21}$.

The neuronal pathway that regulates cardiovascular parameters in a hypovolemic condition is not well defined. However, besides RVLM, numerous brain areas, such as the supra-optic nucleus (SON), the paraventricular nucleus (PVN), and raphe nuclei may be implicated in brain response to hypotension ${ }^{20}$. Furthermore, it has been indicated that the $\mathrm{CnF}$ has a relationship with PVN and raphe nuclei. Thus, the $\mathrm{CnF}$ may exert its effect on the cardiovascular system via its connections with the PVN and/or raphe nuclei.

The $\mathrm{CnF}$ is a heterogeneous nucleus and contains several neural groups such as glutamatergic ${ }^{22}$, GABAergic ${ }^{23}$, cholinergic $^{24}$, and opioidergic ${ }^{22}$ and serotonergic neurons. Our previous studies indicated that serotonergic and opioid pathways of the $\mathrm{CnF}$ are involved in the regulation of the cardiovascular system during hemorrhage $\mathrm{e}^{13,14}$. It has also been reported that the $\mathrm{CnF}$ is an integrative area that mediates the cardiovascular response to a stressor such as hypotension. Therefore, hypotension signals from baroreceptors, chemoreceptors, and volume receptors project to the $\mathrm{CnF}$, and this nucleus, via other areas, precipitate the cardiovascular responses for the maintenance of hypovolemic conditions.

An important limitation of this study is that we did not discriminate individual neuronal groups. If responses of individual neuronal groups were examined separately, their effects on hypotension could be better evaluated.

In summary, the current preliminary findings revealed that neurons of the $\mathrm{CnF}$ responded to both hypovolemic and non-hypovolemic hypotension and this neural activity did not differ between these conditions. However, further studies are needed to evaluate the exact mechanisms of these responses.

\section{References}

1. Barrett KE, Barman SM, Boitano S, Brooks HL. Ganong's Review of Medical Physiology (Enhanced EB). Lange medical book. 23rd ed. New York: McGraw Hill Professional; 2009.

2. Palkovits M. Interconnections between the neuroendocrine hypothalamus and the central autonomic system: Geoffrey Harris Memorial Lecture, Kitakyushu, Japan, October 1998. Front Neuroendocrinol. 1999 Oct;20(4):270-95. https://doi.org/10.1006/ frne.1999.0186

3. Carlson JD, lacono RP, Maeda G. Nociceptive excited and inhibited neurons within the pedunculopontine tegmental nucleus and cuneiform nucleus. Brain Res. 2004 Jul;1013(2):182-7. https://doi. org/10.1016/j.brainres.2004.03.069

4. Nasimi A, Shafei MN, Alaei H. Glutamate injection into the cuneiform nucleus in rat, produces correlated single unit activities in the Kolliker-Fuse nucleus and cardiovascular responses. Neuroscience. 2012 Oct;223:439-46. https://doi.org/10.1016/j. neuroscience.2012.07.041

5. Korte SM, Jaarsma D, Luiten PGM, Bohus B. Mesencephalic cuneiform nucleus and its ascending and descending projections serve stressrelated cardiovascular responses in the rat. J Auton Nerv Syst. 1992 Nov;41(1-2):157-76. https://doi.org/10.1016/0165-1838(92)90137-6

6. Verberne AJ. Cuneiform nucleus stimulation produces activation of medullary sympathoexcitatory neurons in rats. Am J
Physiol. 1995 Mar;268(3 Pt 2):R752-8. https://doi.org/10.1152/ ajpregu.1995.268.3.R752

7. Rossaint R, Cerny V, Coats TJ, Duranteau J, Fernández-Mondéjar E, Gordini G, et al. Key issues in advanced bleeding care in trauma. Shock. 2006 Oct;26(4):322-31. https://doi.org/10.1097/01. shk.0000225403.15722.e9

8. Badin J, Boulain T, Ehrmann S, Skarzynski M, Bretagnol A, Buret J, et al. Relation between mean arterial pressure and renal function in the early phase of shock: a prospective, explorative cohort study. Crit Care. 2011;15(3):R135. https://doi.org/10.1186/cc10253

9. Ahlgren J, Porter K, Hayward LF. Hemodynamic responses and c-Fos changes associated with hypotensive hemorrhage: standardizing a protocol for severe hemorrhage in conscious rats. Am J Physiol Regul Integr Comp Physiol. 2007 May;292(5):R1862-R71. https://doi. org/10.1152/ajpregu.00325.2006

10. Farrokhi E, Shafei MN, Khajavirad A, Hosseini M, Bideskan ARE. Role of the nitrergic system of the cuneiform nucleus in cardiovascular responses in Urethane-Anesthetized male rats. Iran J Med Sci. 2017 Sep;42(5):473-80.

11. Shafei MN, Nasimi A. Effect of glutamate stimulation of the cuneiform nucleus on cardiovascular regulation in anesthetized rats: Role of the pontine Kolliker-Fuse nucleus. Brain Res. 2011 Feb;1385:135-43. https://doi.org/1016/j.brainres.2011.02.046 
12. Shafei MN, Niazmand S, Hosseini M, Daloee MH. Pharmacological study of cholinergic system on cardiovascular regulation in the cuneiform nucleus of rat. Neurosci Lett. 2013 Aug;549:12-7. https:// doi.org/10.1016/j.neulet.2013.05.046

13. Mohebbati R, Hosseini M, Khazaei M, Rad AK, Shafei MN. Involvement of the 5-HT1A receptor of the cuneiform nucleus in the regulation of cardiovascular responses during normal and hemorrhagic conditions. Iran J Basic Med Sci. 2020 Jul;23(7):858-64. https://doi.org/10.22038/ijbms.2020.40453.9579

14. Mohebbati R, Rad AK, Hosseini M, Shafei MN. Effect of opioid receptors of the cuneiform nucleus on cardiovascular responses in normotensive and hypotensive hemorrhagic rats. Neurosci Lett. 2021 Feb;745:135582. https://doi.org/10.1016/j.neulet.2020.135582

15. Nasimi A, Kafami M. Vasopressin and sympathetic system mediate the cardiovascular effects of the angiotensin II in the bed nucleus of the stria terminalis in rat. Neurosci Res. 2016 Jul;108:34-9. https:// doi.org/10.1016/j.neures.2016.01.003

16. Paxinos $\mathrm{G}$, Watson $\mathrm{C}$. The rat brain in stereotaxic coordinates. San Diego: Elsevier Academic Press; 2005.

17. Mohebbati R, Hosseini M, Khazaei M, Shafei MN. Cardiovascular effect of cuneiform nucleus during hemorrhagic hypotension. Basic Clin Neurosci. 2020 May-Jun;11(3):251-9. https://doi.org/10.32598/ bcn.11.2.84.4

18. Badoer E, McKinley MJ, Oldfield BJ, McAllen RM. A comparison of hypotensive and non-hypotensive hemorrhage on Fos expression in spinally projecting neurons of the paraventricular nucleus and rostral ventrolateral medulla. Brain Res. 1993 May;610(2):216-23. https://doi.org/10.1016/0006-8993(93)91403-F

19. Cavun S, Resch GE, Evec AD, Rapacon-Baker MM, Millington WR. Blockade of delta opioid receptors in the ventrolateral periaqueductal gray region inhibits the fall in arterial pressure evoked by hemorrhage. JPET. 2001 May;297(2):612-9.

20. Dampney RAL, Horiuchi J. Functional organisation of central cardiovascular pathways: studies using c-fos gene expression. Prog Neurobiol. 2003 Dec;71(5):359-84. https://doi.org/10.1016/j. pneurobio.2003.11.001

21. Graham JC, Hoffman GE, Sved AF. c-Fos expression in brain in response to hypotension and hypertension in conscious rats. J Auton Nerv Syst 1995 Oct;55(1):92-104. https://doi.org/10.1016/0165-1838(95)00032-S

22. Haghparast A, Gheitasi IP, Lashgari R. Involvement of glutamatergic receptors in the nucleus cuneiformis in modulating morphineinduced antinociception in rats. Eur J Pain. 2007 Nov;11(8):855-62. https://doi.org/10.1016/j.ejpain.2006.12.010

23. Margeta-Mitrovic M, Mitrovic I, Riley RC, Jan LY, Basbaum AI. Immunohistochemical localization of GABAB receptors in the rat central nervous system. J Comp Neurol. 1999 Mar;405(3):299-321. https://doi.org/10.1002/(SICI)1096-9861(19990315)405:3<299::AIDCNE2>3.0.CO;2-6

24. Behbehani MM, Zemlan FP. Response of nucleus raphe magnus neurons to electrical stimulation of nucleus cuneiformis: role of acetylcholine. Brain Res. 1986 Mar;369(1-2):110-8. https://doi. org/10.1016/0006-8993(86)90518-4 